\title{
The Effect of Jacobson's Progressive Muscular Relaxation on Sleep Quality in Elderly at Budi Agung Social Institution
}

\author{
Dyah G. R. Kareri ${ }^{1}$, Derri R. Tallo Manafe ${ }^{2}$, Maria Kurniati Ester Payong ${ }^{3}$ \\ ${ }^{1}$ Medical Rehabilitation Department Faculty of Medicine Nusa Cendana University, Kupang, Indonesia \\ ${ }^{2}$ Physiology Department Faculty of Medicine Nusa Cendana University, Kupang, Indonesia \\ ${ }^{3}$ Faculty of Medicine Nusa Cendana University, Kupang, Indonesia
}

\begin{abstract}
Background: The quality of sleep in elderly tend to decline. This occurs as a result of certain changes such as physical, biological, mental and socio-economic. The quality of sleep may influence the health condition for short or long terms. Poor quality of sleep may cause difficulty in concentrating, slow response, memory disturbance and decrease of performance in daily life. The decline of sleep quality may be resolved with Jacobson's Progressive Muscular Relaxation (JPMR) exercise.
\end{abstract}

Objective: To analyze the effect of Jacobson's Progressive Muscular Relaxation on sleep quality in elderly at Budi Agung Social Institution.

Methods: This study is a pre experimental study with one group pretest-posttest design. The subject of this study were the 19 elderly at Budi Agung Social Institution. In this study, JPMR exercise was done in 5 days. Sleep quality before and after JPMR exercise was measured using Pittsburgh Sleep Quality Index (PSQI) questionnair. The data obtained was analyzed using McNemar test.

Results: From a total of 19 subjects, 3 subjects had good sleep quality while 16 subjecst had poor sleep quality. On the other hand, after the JPMR excercise, improved sleep qualiy was found in the 16 subjects while the 3 subjects still had poor sleep quality; bivariate analysis $p$ value $=0.002(\mathrm{p}<0.05)$.

Conclusion: Jacobson's Progressive Muscular Relaxation (JPMR) has a significant effect on sleep quality in elderly at Budi Agung Social Institution.

Keywords: elderly, sleep quality, Jacobson's Progressive Muscular Relaxation, Pittsburgh Sleep Quality Index. 


\title{
Pengaruh Jacobson's Progressive Muscular Relaxation terhadap Kualitas Tidur Pada Lansia Di UPT Kesejahteraan Sosial Lanjut Usia Budi Agung
}

\author{
Dyah G. R. Kareri ${ }^{1}$, Derri R. Tallo Manafe ${ }^{2}$, Maria Kurniati Ester Payong ${ }^{3}$
}

\author{
${ }^{1}$ Departemen Rehabilitasi Medik Fakultas Kedokteran Universitas Nusa Cendana. \\ ${ }^{2}$ Departemen Fisiologi Fakultas Kedokteran Universitas Nusa Cendana \\ ${ }^{3}$ Fakultas Kedokteran Universitas Nusa Cendana
}

\begin{abstract}
ABSTRAK
Latar belakang: Lanjut usia (lansia) cenderung mengalami penurunan kualitas tidur. Hal ini terjadi karena pada lansia terjadi berbagai perubahan baik fisik, biologis, mental maupun sosial ekonomi. Kualitas tidur mempengaruhi kesehatan manusia baik untuk hari itu maupun jangka panjang. Efek yang dapat ditimbulkan oleh kualitas tidur yang buruk antara lain kesulitan menaruh perhatian, respon menjadi lambat, gangguan memori dan konsentrasi, serta penurunan performa. Penurunan kualitas tidur dapat diatasi dengan latihan Jacobson's Progressive Muscular Relaxation (JPMR).
\end{abstract}

Tujuan: Membuktikan pengaruh Jacobson's Progressive Muscular Relaxation terhadap kualitas tidur pada lansia di UPT Kesejahteraan Sosial Lanjut Usia Budi Agung.

Metode penelitian: Penelitian ini merupakan penelitian pre eksperimental dengan rancangan one group pretestposttest. Subyek penelitian ini adalah 19 lansia yang ada di UPT Kesejahteraan Sosial Lanjut Usia Budi Agung. Latihan JPMR dalam penelitian ini dilakukan selama 5 hari berturut-turut. Kualitas tidur sebelum dan sesudah latihan JPMR diukur dengan kuesioner Pittsburgh Sleep Quality Index (PSQI). Analisa data menggunakan uji McNemar.

Hasil: Dari total 19 subyek, pada tahap pre tes didapatkan 3 subyek memiliki kualitas tidur baik, dan 16 subyek memiliki kualitas tidur buruk. Setelah latihan JPMR didapatkan perbaikan kualitas tidur, dimana terdapat 16 subyek dengan kualitas tidur baik dan 3 subyek dengan kualitas tidur buruk. Berdasarkan hasil analisis bivariat didapatkan nilai $\mathrm{p}=0,002(\mathrm{p}<0,05)$.

Kesimpulan: Jacobson's Progressive Muscular Relaxation (JPMR) memiliki pengaruh yang signifikan terhadap kualitas tidur pada lansia di UPT Kesejahteraan Sosial Lanjut Usia Budi Agung.

Kata Kunci: lanjut usia, kualitas tidur, Jacobson’s Progressive Muscular Relaxation, Pittsburgh Sleep Quality Index.

Correspondent Detail:

\section{Dyah G. R. Kareri}

Email: yaya.rk@yahoo.com

Department of Physical Medicine and Rehabilitation, Nusa Cendana University, Kupang, Indonesia 


\section{INTRODUCTION}

Elderly is a process from a healthy adult who experiences a process of change into a weak and vulnerable person caused by the reduction in most of the physiological system thus increased the susceptibility to various diseases and deaths ${ }^{1}$. Many developing countries use the age of $\geq 65$ years as a limitation of the elderly, but the World Health Organization (WHO) and the United Nations (UN) agree to use the age of $\geq 60$ years as a limitation of the elderly ${ }^{2}$.

According to the World Population Prospects report: The 2012 revision of the elderly population around the world is predicted to increase ${ }^{3}$. The population of elderly people in Indonesia in 2015 was $8.5 \%$ of the total population and is predicted to increase up to $28.68 \%$ in $2050^{3,4}$. In 2015 the estimated percentage of the elderly population in East Nusa Tenggara was $7.5 \%{ }^{4}$.

There have been various changes in the elderly occurring, such as deteriorating sleep quality. Sleep quality affects human health both for the short and the long term ${ }^{5}$.

According to McCall, sleep disturbances in the elderly are associated with increased morbidity and mortality, so that adequate therapy is needed in handling sleep disorders ${ }^{6}$.

Broadly speaking, there are handling sleep disorders could be done as non-pharmacological and pharmacological therapies. Pharmacological therapy has side effects in the form of psychomotor disorders especially in the elderly ${ }^{7}$. Due to the many side effects of the pharmacological therapy, the researchers began to look for alternatives in the treatment of sleep disorders ${ }^{8}$.
The American Psychological Association (APA) recommended three types of non-pharmacological therapy as an alternative in the treatment of sleep disorders, namely stimulus control, paradoxical intention, and progressive muscle relaxation $(\mathrm{PMR})^{7,9}$.

According to Borkovec, stimulus control is the most potent therapy in dealing with sleep disorders ${ }^{10}$. However,other researchers suggest that there is no difference in the efficacy between PMR, stimulus control and paradoxical intention ${ }^{8}$. Espie, et al.(1989) stated that even though the control stimulus can cause a better change in sleep latency, this trait is only temporary. As with progressive muscle relaxation, where there is an improvement in the quality of sleep that lasts long ${ }^{11}$.

Progressive muscle relaxation (PMR) is a method of relaxation according to Edmund Jacobson developed around the 1930s. The basic principle of Jacobson's Progressive Muscular Relaxation (JPMR) is muscle tension followed by relaxation ${ }^{9}$. Relaxation can provide emotional balance and peace of mind. Davis (1995) stated that subjects who do JPMR may experience easier to fall asleep ${ }^{12}$. According to a study conducted by Sitralita in Batusangkar in 2010, there was an increase in sleep quality in elderly after PMR, where the value of $p<0.05^{13}$. This result is on the contrary to previous studies conducted by Hauri, et al. who stated that deterioration in sleep quality in insomnia patients after performing JPMR ${ }^{14}$.

The purpose of this study is to determine the effect of JPMR on sleep quality in the elderly at the Budi Agung Elderly Social Welfare UPT, as well as to identify the quality of sleep before and after JPMR training in elderly. 


\section{METHODS}

This study is a pre-experimental research with the design of one group pretest-posttest. The study was conducted at the Budi Agung Elderly Social Welfare UPT during August 2017.

The sample in this study were 19 subjects obtained using total sampling technique. Data was analyzed using McNemar test.

\section{RESULTS}

There were 23 subjects obtained for this study from the residents of Budi Agung Elderly Social Institution. During the study, there were four dropout elderlies as subjects in this research because they did not take part in the JPMR training for five consecutive days. Thus, the total subjects in this study were 19 subjects.

The characteristics of the research subjects, in general, can be seen in Table 1. The number of female subjects in the present study was dominant than that of men, with an average age of subjects who attended the study was 73 years old. Meanwhile, the average Body Mass Index (BMI) of the subjects who took part in the study was $21.87 \mathrm{~kg} / \mathrm{m}^{2}$. In this study, there were six subjects who were in an unhealthy condition. The types of diseases suffered by the six subjects included: hypertension, dermatitis, and gout. The number of healthy subjects is advantageous for the study, which is lower compared to the unhealthy subjects. Meanwhile the gender aspect did not affect the result of the study.
Tabel 1. The Characteristics of Research Subjects

\begin{tabular}{lc}
\hline \multicolumn{1}{c}{ Variabel } & $\begin{array}{c}\text { N }(\%) \text { or } \\
\text { median }(\min -\max )\end{array}$ \\
\hline $\begin{array}{l}\text { Gender: } \\
\text { Female } \\
\text { Male }\end{array}$ & $11(57,9)$ \\
Age (years) & $8(42,1)$ \\
Medical Condition: & $75,00(60-80)$ \\
Unhealthy & $6(31,6)$ \\
Healthy & $13(68,4)$ \\
BMI (kg/m $\left.{ }^{2}\right)$ & $21,87(17,10-28,90)$ \\
\hline BMI : Body Mass Index &
\end{tabular}

Furthermore, Table 2 presented that there were six subjects who had good sleep quality and 13 other subjects had poor sleep quality before the JPMR training. A total of 10 subjects who had poor sleep quality in the pre-test was improved and six subjects who had good sleep quality in the pretest did not experience deterioration. Therefore, 16 subjects who had good sleep quality in the posttest were obtained.

Bivariate analysis using the McNemar test obtained a significance value of $0.002(p<0.05)$,

Table 2. Sleep Quality Before JPMR Exercises

\begin{tabular}{cccc}
\hline Variabel & Pre test & Post test & $\mathrm{p}$ \\
\hline $\begin{array}{c}\text { Good } \\
\text { sleep }\end{array}$ & 6 & 16 & \\
quality & $(31,58 \%)$ & $(84,21 \%)$ & 0,002 \\
& & & \\
Poor & 13 & 3 & \\
sleep & $(68,42 \%)$ & $(15,79)$ & \\
quality & & & \\
\hline
\end{tabular}

It can be concluded that Jacobson's Progressive Muscular Relaxation (JPMR) has a significant influence on sleep quality in the elderly at the Budi Agung Elderly Social Institution.Based 
on the results of interviews using the PSQI questionnaire before JPMR training, there were $42.11 \%$ of subjects with excellent sleep quality. After the JPMR exercise there was an increase in subject satisfaction with the quality of sleep, which was $73.68 \%$. This increase in the quality of subjective sleep can occur due to improvements in other sleep quality components, such as sleep latency, sleep duration, and sleep efficiency.

Another component of sleep quality that also experiences improvement is sleep disturbances. At the pre-test stage there were $63.16 \%$ of subjects with poor sleep disturbances and only $15.79 \%$ of subjects with good sleep disorders. After the JPMR exercise, there were $78.95 \%$ of subjects with good sleep quality and only $10.53 \%$ of the subjects with poor sleep disorders.

In this study, there was no use of sleeping pills on subjects both before and after JPMR training.

\section{DISCUSSION}

Before JPMR training there were only $26.32 \%$ of subjects with disruption of activity, which then increased to $94.74 \%$ of subjects.

The assesment of sleep quality using the PSQI questionnaire consisted of seven components: subjective sleep quality, sleep latency, sleep duration, sleep efficiency, sleep disturbances, use of sleeping pills, and disruption of activity ${ }^{13}$.

Subjective sleep quality were also increased after the JPMR exercise. Based on the research of Sulidah et al. (2016), JPMR training was effective enough to shorten sleep latency, prolong sleep duration, improve sleep efficiency, reduce sleep disturbances, and reduce disruption of activity during the day thereby increase the satisfaction responses to sleep quality of subjects ${ }^{14}$.

Sleep latency is describe as the time needed to fall asleep measured by the time needed to start sleep and the frequency of sleep disability in 30 minutes $^{14}$. In this study, $47.4 \%$ of the subjects needed more than 60 minutes to begin sleeping before JPMR training was conducted. This is in line with Reid et al. (2006) that stated the difficulty of falling asleep is the most common problem experienced by the elderly ${ }^{15}$. After JPMR exercises, there was an improvement in sleep latency from the subjects. JPMR's effect on improving sleep latency was suggested by Conrad \& Roth (2007) that the JPMR technique is able to control the activity of the autonomic nervous system and the suprachiasmatic nucleus activity making it easier for subjects to start sleeping ${ }^{16}$.

Improvement of sleep latency after JPMR training was followed by an increase in sleep duration and sleep efficiency. In the elderly, there is a change in circadian rhythms so that the elderly tend to have a shorter sleep at night and wake up early so that there will be a decrease in the duration and efficiency of sleep ${ }^{17,18 .}$ Improvement of the duration and efficiency of the subjects' sleep was obtained from the effects of JPMR in improving sleep latency and overcoming sleep disturbances in the subjects.

Improving the sleep quality of subjects after JPMR training was also accompanied by the reduced sleep disturbance of the subjects. Before JPMR's training, many elderly people complained of pain during the night, but after JPMR exercise 
this complaint decreased. This is due to the JPMR effect on stress reduction; when stress decreases, the pain felt will also decrease ${ }^{19}$.

Some subjects also complained of difficulty of breathing at night, and had nightmares. These were also decreased after JPMR's training. According to Saeedi, et al. JPMR can reduce sleep disturbances resulting in improvements in sleep quality ${ }^{20}$.

This study did not use any sleeping drugs either before or after JPMR training. Sulidah (2016) in her research stated that the frequency of using drugs to help sleep illustrates the severity of sleep disorders experienced by the elderly ${ }^{14}$. This statement cannot be applied to the subjects in this study because even though the subjects did not take sleeping pills, they still did not take sleeping pills, $68,42 \%$ of the subjects had poor sleep quality at the pre-test stage.

The last component assessed in the PSQI questionnaire is the inteference of daytime activity. Based on the results of the interview at the pre- test stage, there were subjects who had difficulty maintaining wakefulness when involved in social activities. This is due to the short sleep duration and sleep disturbances experienced at night can cause difficulties in daytime activities ${ }^{17}$.

\section{CONCLUSION}

The result of the study can be concluded that Jacobson's Progressive Muscular Relaxation (JPMR) has a significant influence on sleep quality in the elderly at Budi Agung Elderly Social Welfare UPT.
From a total of 19 subjects there were 6 subjects who had good sleep quality and 13 subjects had poor sleep quality before the Jacobson's (JPMR) exercise. From a total of 19 subjects there were 16 subjects who had good sleep quality and 3 subjects had poor sleep quality after Jacobson's (JPMR) exercise.

\section{REFERENCES}

1. Setiati S, Harimurti K, Govinda A. Books on Internal Medicine. $5^{\text {th }}$ Ed. Jakarta ; Publisher Office of the University of Medicine Faculty: 2009.

2. WHO. Elderly population [Internet] 2020 [cited 2020 Nov 21]. Available from: www. searo.who.int

3. Indonesian Ministry of Health. Overview of Elderly Health in Indonesia. Jakarta: Kemkes; 2013.

4. Indonesian Ministry of Health. The situation of the elderly in Indonesia. Jakarta : Kemkes; 2016.

5. Luo J, Zhu G, Zhao Q, Guo Q, Meng H, Hong $Z$, et al. Prevalence and risk factors of poor sleep quality among chinese elderly in an urban community: Results from the Shanghai aging study. PLoS One. 2013;8(11):1-7.

6. McCall WV. Sleep in the Elderly: Burden, Diagnosis, and Treatment. Prim Care Companion J Clin Psychiatry. 2008;6(1):9-20.

7. Ashton H. When and What to Use Guidelines for the Rational Use of Benzodiazepines. Drugs. 1994;48(1):25-40. 
8. Murtagh DRR, Greenwood KM. Identifying Effective Psychological Treatments for Insomnia: A Meta-Analysis. 1995;63(1):1015 .

9. Morin CM, Bootzin RR, Buysse DJ, Edinger JD, Espie C a, Lichstein KL. Psychological and behavioral treatment of insomnia: Update of the recent evidence (1994-2004). Sleep. 2006;29(11):1398-414.

10. Borkovec TD. Insomnia. J Consult Clin Psychol. 1982; 50:880-95.

11. Espie CA, Lindsay WR, Brooks DN, Hood EM, Turvey T. A controlled comparative investigation of psychologycal treatments for chronic sleep onset for insomnia in the older adult. Behav Res Ther. 1989; 27:79-88.

12. Davis M, Eshelman ER, McKay M. Guide to Relaxation and Stress Reduction. $3^{\text {rd }}$ ed. Jakarta: Medical Book Publisher EGC; 1995.

13. Smyth CA. How to Evaluating Sleep Quality in Older Adults. 2008;108(5) : 280-5

14. Sulidah, Yamin A, Susanti R. The Effect of Progressive Muscle Relaxation Exercise towards Older People's Quality of Sleep. 2016;4(April):11-20.
15. Reid K, Z M, Finkel S, Statsinger J, Golden R, Harter K, et al. A Marker of Physical and Mental Health in the Elderly. Am J Geriatr Psychiatry. 2006;14:860-6.

16. Conrad A, Roth WT. Muscle relaxation therapy for anxiety disorders: It works but how ? J Anxiety Disord. 2007; 21: 243-64

17. Prayitno A. Disorders of sleep patterns in the elderly and management. Trisakti Medical Journal. 2002; 2(1):23-30.

18. Zarcone P, Falke R, Anlar O. Effect of progressive relaxation on sleep quality. Neuroscience. 2010;63: 221-7.

19. Persson AL, Veenhuizen H, Zachrison L, Gard G. Relaxation as treatment for chronic musculoskeletal pain - a systematic review of randomised controlled studies. Physical Therapy Reviews. 2008;13(5) : 355-66

20. Saeedi C. The effect of progressive muscle relaxation on sleep quality of patients undergoing hemodialysis. Iran J Crit Care Nurs. 2012;5(1):23-8. 